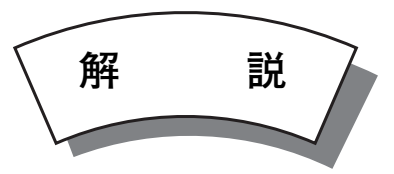

\title{
燃料多様化と負荷追従性に優れた微粉炭燃焼技術の開発 \\ Development of Pulverized Coal Combustion Technology for Fuel Diversification and High Turn Down Capability
}

\author{
丹野賢二*・牧野尚夫* \\ Kenji TANNO and Hisao MAKINO
}

Key Words: Pulverized Coal Combustion, Fuel Diversification, High Turn Down Capability, NOx Emission, Numerical Simulation

\section{1.はじめに}

石炭は可採埋蔵量が多く、また産炭国にも極端な偏りが ないので、長期的に安定供給が可能な化石燃料として非常 に注目されている。石炭の可採年数（現在、確認されてい る経済的に採掘が可能な石炭の資源量すなわち可採埋蔵量 を、前年の石炭使用量で除算したもの）は 100 年以上と計 算されているが、この数值は、すべての石炭種を含めて計 算した值であり、現在、主に使用されている瀝青炭だけし か使用できない場合には、この可採年数は大幅に低下する。 石炭の可採埋蔵量が多いという特徵を活かすためには、あ らゆる種類の石炭を使用できるようにする必要がある。ま た石炭は、他の化石燃料に比べて炭素比率が高く、それに 伴い地球温暖化に関わりの深い二酸化炭素 $\left(\mathrm{CO}_{2}\right)$ 排出量が 多いという問題もある。 $\mathrm{CO}_{2}$ 排出量を低減するためには、 石炭使用量を低減できる高効率な発電方式を採用する必要 があり、多様な石炭を使用した場合、それらの全ての石炭 種において、高い発電効率を発揮できることが要求される。
$\mathrm{CO}_{2}$ 排出低減に関しては、近年ますます要求が㛜しくなっ ており、太陽光、風力、バイオマスなどの自然エネルギー、 再生可能エネルギーの利用が拡大されている。しかし、こ れらの発電方式における出力は、気象状況、季節によって 変動するため、安定した電力供給のためには、他の発電方 式で、この出力変動分を吸収できるよう出力調整をする必 要がある。また、電気の需要は昼夜および季節によっても 異なるため、電力供給の調整は非常に重要となり、現在そ の役割は火力発電所が担っている。

すなわち、今後の石炭火力においては、様々な石炭種が 利用でき、かつ速やかな出力調整をできることが不可欠とな る。本稿では、石炭の主要な発電方式である微粉炭火力にお ける、燃料多様化と高い負荷追従性を達成するために開発さ れている技術を概説するとともに、今後の展望を述べる。

\section{2. 微粉炭火力の概要と特徵}

現在、発電用の石炭火力技術としては、ほとんどが Fig.1 にフローを示す微粉炭燃焼火力が用いられている。石炭火

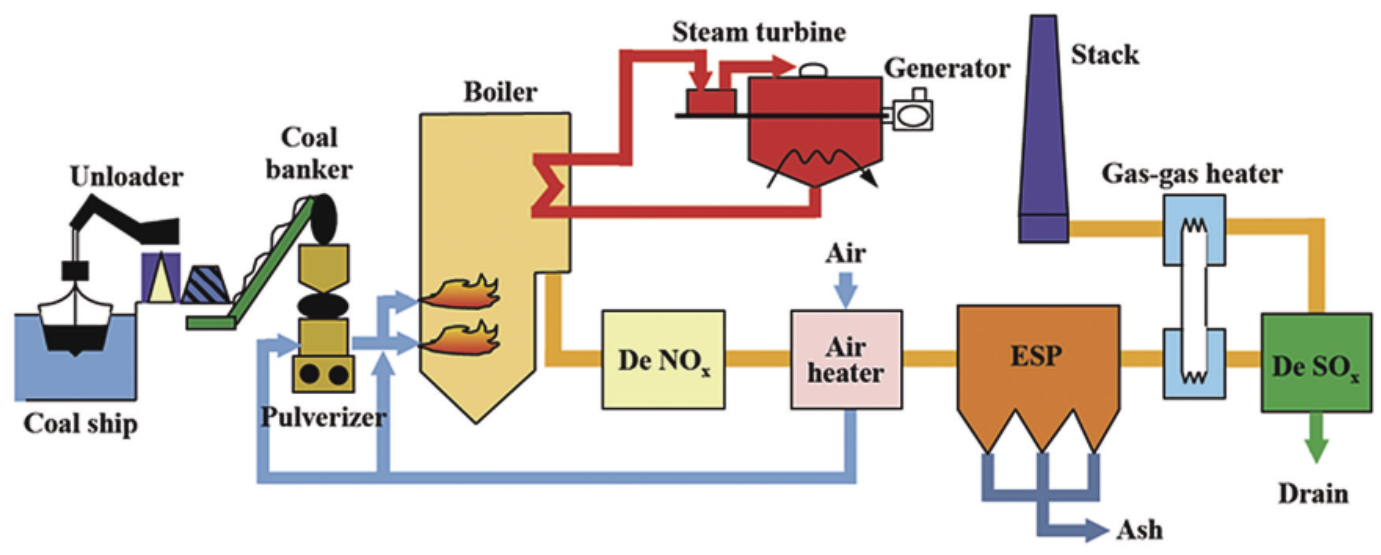

Fig.1 Schematics of a pulverized coal-fired power plant.

*一般財団法人 電力中央研究所エネルギー技術研究所（† 240-1096 神奈川県横須賀市長坂 2-6-1）

Central Research Institute of Electric Power Industry Energy Engineering Research Laboratory (2-6-1 Nagasaka, Yokosuka, Kanagawa, 240-0196 Japan) 
力で使用するほぼ全部の石炭を輸入に頼っている我が国で は、オーストラリアなどの産炭国から海上輸送により石炭 を搬入し、港での揚炭、ベルトコンベアによる輸送を経て、 貯炭場にて保管された後に利用される。以下ではまず、微 粉炭火力のフローの概要と特徵について述べる。

発電所近傍の港で受け入れた後の石炭は、屋外貯炭方式 または、サイロ等を用いた屋内貯炭方式のいずれかで保管 される。この保管場所から、必要に応じて発電設備の方に 石炭が送られることになる。石炭を、火力発電用の燃料と して利用するにあたっては、搬送しやすく、かつ高効率で 燃焼しやすい微粉炭にする方法が容易となる。最近の微粉 炭火力では、ローラーミルにより石炭を粉砕し、微粉炭を 製造していることが多くなっている。微粉炭の粒子径は、 次章で詳しく述べるが、燃焼時の $\mathrm{NO}_{\mathrm{x}}$ 生成特性や燃焼効率 向上による未燃損失の低減などの環境保全性にも大きく影 響するため、その管理は非常に重要である。これまでは中 位径 $40 \mu \mathrm{m}$ 程度が、燃焼特性と粉砕動力のバランスから考 え最適とされていたが、最近では、より微細な微粉炭利用 時に $\mathrm{NO}_{\mathrm{x}}$ や未燃損失分の低減効果が大きくなることを考慮 し、ミルの高性能化に伴い、中位径を $10 \mu \mathrm{m}$ 程度まで細か くして利用する技術なども提案されている。微粉炭燃焼後 に発生した熱はボイラにおいて蒸気に伝え、高温・高圧の 蒸気で稼働する蒸気タービンにて発電する。ボイラを出た 燃焼ガスは、触媒式脱硝装置による $\mathrm{NO}_{\mathrm{x}}$ 低減、電気集じん 装置による粒子状物質の除去、湿式脱硫装置による $\mathrm{SO}_{\mathrm{x}}$ 分 離などの排ガス処理を経てクリーンにされた後、煙突から 排出される。

\section{3. 微粉炭火力における燃料多様化技術}

微粉炭火力で多様な石炭を用いる上で、石炭の性状を表 す様々な因子に注目する必要があるが、最も重要なのは然 焼性である。石炭中の可燃分を、高温場で容易にガス状に 転換する揮発分と、固体状で残留する固定炭素分とに分け、 その比率（固定炭素分／揮発分）を示した数值は燃料比と 呼ばれ、石炭の炭化レベルを表すとともに、石炭の燃焼性 を表す指標としてもよく用いられる。燃料比が大きいほど、 石炭の炭化が進み着火しにくい特徵をもつ。これまで、微 粉炭火力においては、燃料比が $1 \sim 2.5$ 程度の適度に炭化 した瀝青炭が用いられて来た。しかし近年、世界的な石炭 利用量の増大から瀝青炭の入手が困難になり、炭化が進ん でいない低品位炭（亜瀝青炭や褐炭）の利用が注目されて いる。

石炭の燃焼にあたっては、窒素酸化物 $\left(\mathrm{NO}_{\mathrm{x}}\right)$ の生成を極 力抑制すると共に、生成する石炭灰を有効利用しやすい性 状とするため灰中未燃分濃度を $3 \%$ 以下にできるよう燃焼 効率を高く調整するなど、高度な燃焼制御が必要となる。 近年、微粉炭燃焼時の $\mathrm{NO}_{\mathrm{x}}$ と灰中未燃分を同時に低減する ため、Fig.2 に示すような概念の燃焼火炎 ${ }^{1), 2}$ を実現するこ

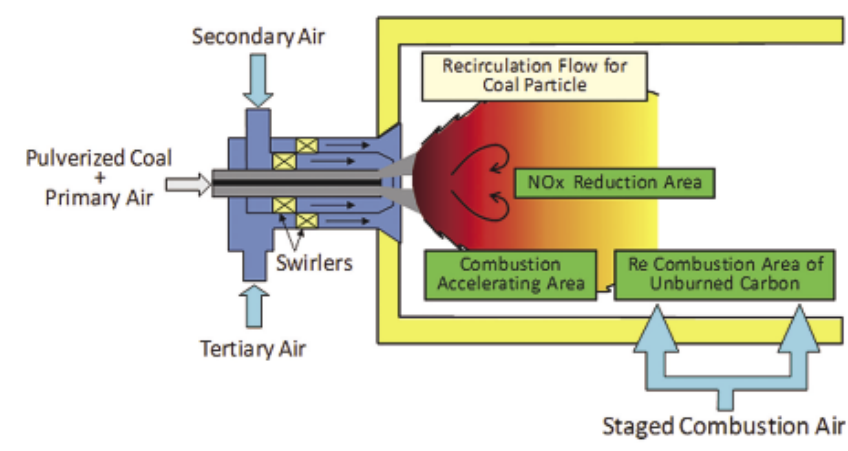

Fig.2 Concept of advanced combustion technology.

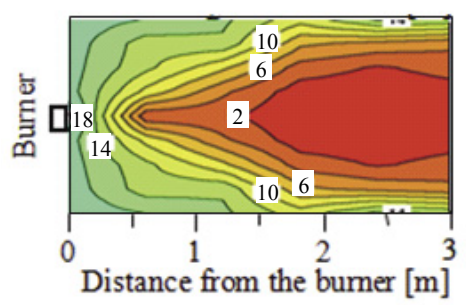

(a) Bituminous coal

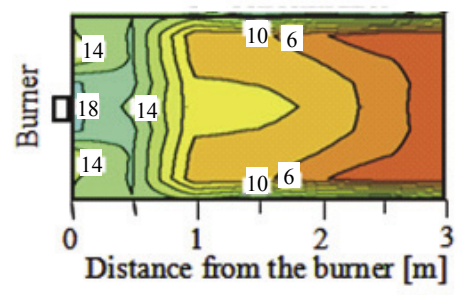

(b) Sub-bituminous coal

Fig.3 Oxygen concentration distribution in the burner zone.

とが有効であると考えられている。すなわち、バーナ近傍 の高温燃焼火炎の中に微粉炭粒子を長く滞留できるための 再循環流を形成し、速やかな酸素消費による $\mathrm{NO}_{\mathrm{x}}$ 還元炎の 効果的形成と石炭の燃焼促進を図れるように、微粉炭粒子 の挙動を制御することが求められている。そのためには、 バーナからの空気噴出孔形状や空気注入条件が微粉炭粒子 の挙動に及ぼす影響を明らかにし、最も効果的に還元炎の 形成と燃焼促進を図れる構造にする必要がある。

Fig.3 は、上記の燃焼概念を実現できるバーナで、通常 の瀝青炭と亜瀝青炭を燃焼させた場合の火炎内酸素濃度分 布を示したものである ${ }^{3)}$ 。酸素の消費は燃焼の進行と関連 するため、酸素濃度分布から燃焼過程を把握することがで きる。瀝青炭燃焼時の酸素濃度分布を示す上図においては、 バーナ噴出孔から火炎が滑らかに広がり、かつバーナ中心 軸上では酸素の消費が極めて速く、酸素濃度が $2 \%$ 以下で 酸素がほとんど存在しない領域が形成されていることが分 


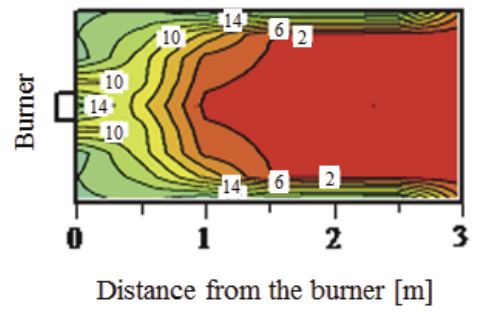

Fig.4 Oxygen concentration distribution in the burner zone in the optimized burner condition for sub-bituminous coal.

かる。この酸素濃度が低い領域は $\mathrm{NO}_{\mathrm{x}}$ を分解する還元域と なり、 $\mathrm{NO}_{\mathrm{x}}$ の効果的な低減に非常に有効になる。これに対 し、下図に示す亜瀝青炭の燃焼火炎は、大きく形状が異な る。中心軸上の酸素濃度の低下が非常に遅く、また火炎は、 バーナ噴出直後から火炉の外側にまで広がるという極端な 傾向を示し、酸素濃度が $2 \%$ 以下となる $\mathrm{NO}_{\mathrm{x}}$ の還元炎の効 果的な形成も図れていないことが明らかである。

亜瀝青炭の燃焼火炎を酸素濃度分布から分析すると、水 分を多量に含んだ状態で火炉内に石炭が注入された際に は、まず水分の蒸発が生じるため着火が遅れることが考え られる。また、水分蒸発後の微粉炭は分裂しやすく、かつ 多孔性の粒子となるため、火炎外周の旋回流に巻き込まれ、 火炎周囲に拡散し易くなっていると考えられる。そこで、 微粉炭粒子の噴出流速を抑制し、火炎外周部の旋回流を弱 めた場合の酸素濃度分布を Fig.4 に示す ${ }^{4)}$ 。Fig.4 は Fig.3 の下図に比べ、明らかに Fig.3の上図の瀝青炭の燃焼火炎 に近い火炎構造となっており、バーナからの微粉炭噴出流 速の抑制および、旋回流の制御が、石炭粒子の挙動制御に 有効に働き、 $\mathrm{NO}_{\mathrm{x}}$ 還元炎の形成や、石炭粒子の燃焼促進に 有効に働いた事が考えられる。

今後は、より水分の多い石炭の利用や、灰分含有率の高 い石炭の利用、粉砕性が悪く大きな微粉炭粒子径の石炭の 利用、さらには極端に炭化が進み高燃料比で着火の悪い石 炭の利用など、さらに多様な石炭を利用していく必要があ ると思われる。微粉炭粒子の大きさ、ならびに共存する水 分や灰分が、微粉炭の燃焼過程や火炎内微粉炭粒子挙動へ の影響の解明を行うとともに、燃料比が高く揮発分が少な い石炭を速やかに着火させるための最適粒子径の把握など を行い、あらゆる石炭種に対して、 $\mathrm{NO}_{\mathrm{x}}$ の発生抑制と燃焼 効率の向上が可能となる、微粉炭粒子径の制御ならびに火 炎内微粉炭粒子挙動の高度な制御方法を確立することが非 常に重要となる。火炎内の微粉炭粒子挙動、ひいては然焼 反応の制御を行う上では、従来の実験的手法に加えて、近 年普及の著しい数值シミュレーションの利用も有効である と考えられる。しかし、現象の複雑な微粉炭燃焼の分野で 数值シミュレーションを活用するためには、その精度を確 認する必要がある。Fig.5 はラボスケールの微粉炭噴流バー

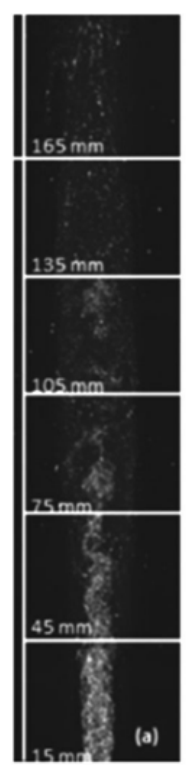

Exp.

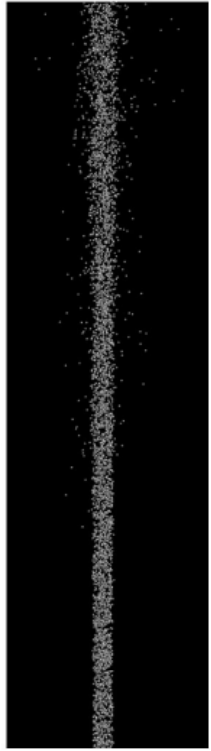

Calc. (a) Particle position

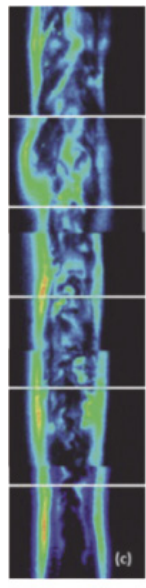

Exp.

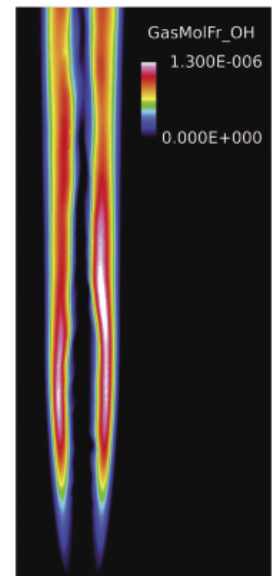

Calc. (b) $\mathrm{OH}$ radical

Fig.5 Instantaneous spatial distributions of (a) coal particle and $\mathrm{OH}$ radical.

ナを対象に数值シミュレーションを行い、その結果得られ た微粉炭粒子位置、および反応帯の指標である $\mathrm{OH}$ ラジカ ルの分布を実験結果と併せて示したものである5)。図より、 微粉炭粒子位置、および反応帯の位置が数值シミュレー ションにより良く捉えられていることがわかる。このよう に、詳細な計測が適用可能なスケールの実験との比較を十 分に行った上で、その精度が十分に保証された数值シミュ レーション技術を活用していくことにより、高度な燃焼制 御技術をより短期間かつ低コストで開発できるようになる と考えられる。 


\section{4. 微粉炭火力の負荷追従性向上技術}

電気の需要は、既に述べたように季節、昼夜などの条件 によって大きく異なるため、需要に応じて供給量を調整す る必要がある。微粉炭火力においては、負荷を下げるため に微粉炭供給量を低減するとバーナ内搬送用空気中の微粉 炭濃度が低下し、燃焼が不安定になるという問題点がある。 一方、搬送用空気量を減少させると、送炭管内で微粉炭が 沈降し易くなり、微粉炭供給が不安定になる。そこで、微 粉炭粒子をバーナ内の局所に濃縮させ、部分的に搬送用空 気中の微粉炭濃度を増加し、着火を安定させる技術が開発 されている。

Fig.6は、石炭を濃縮することが可能なワイドレンジバー ナを用いることにより、安定燃焼できる最低負荷が改善さ れる効果を示したものである ${ }^{6}$ 。約 2 倍に濃縮できれば、 石炭種に関わらず、最低負荷を半分まで低減できることが 明らかである。微粉炭燃焼用バーナで、石炭を濃縮する方 法として最も簡単な方法は、サイクロンなどのように石炭 を濃縮できる装置をバーナ直前に設置し、微粉炭の高濃度 流と低濃度流とに二分した後に、それぞれをバーナから供 給する方法が挙げられる。しかし、バーナ前にサイクロン を設置することは、バーナが大型化するなどの問題がある。 そこで、バーナ内部に簡単な微粉炭濃縮装置を設置するこ とが必要となる。

Fig.7 は、バーナ内部の微粉炭流に旋回を与え、その旋回 流で微粉炭を濃縮しようする概念のワイドレンジバーナを 示したものである ${ }^{0}$ 。微粉炭流はバーナ外周部に接線方向 から流入し、旋回流を形成する。微粉炭粒子は旋回力によ りバーナ外周部に寄せられている。バーナ内部には、台形 状のリングを設置してあり、このリングは外周部に寄せら れた微粉炭を直進させるとともに、旋回流を弱める効果を 持つ。台形リングをバーナ出口近傍に置けば、バーナ外周 部に濃縮した状態の微粉炭をそのまま噴出でき、リングを

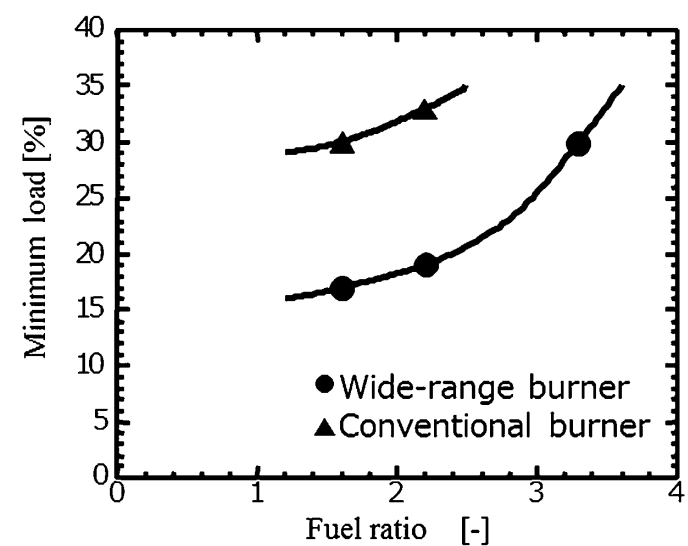

Fig.6 Relationship between minimum load and fuel ratio for each burner.
バーナから離せば、一旦濃縮した微粉炭流が徐々に拡散に より均一濃度になった状態で噴出できる。すなわち、低負 荷時は台形リングをバーナ出口側に寄せて微粉炭を濃縮し た状態で噴出させ、高負荷時には台形リングをバーナ出口 から離して濃縮しない状態で噴出させることで、負荷に関 わらず微粉炭濃度を、ほぼ均一にできるバーナである。こ のような構造のバーナにより、濃縮時には外周部の微粉炭 濃度を、管内平均濃度の 2 倍にまで濃縮できるため、通常 の微粉炭バーナの最低負荷 (40\%) を、その半分 $(20 \%)$ まで 低減できた。その一方で、旋回を使って濃縮するため、バー ナからの微粉炭噴出時にも旋回力が残っており、 $\mathrm{NO}_{\mathrm{x}}$ 還元 炎形成に必要な再循環流に微粉炭が乗り難いという久点も あった。

Fig.8 は、旋回力を用いずに微粉炭を濃縮するために開

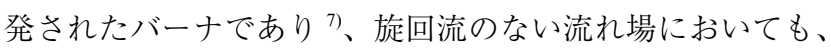
流線式のリングにより滑らかに微粉炭を外周部に濃縮で き、Fig.7のバーナとほほ同等の濃縮機能を有することが

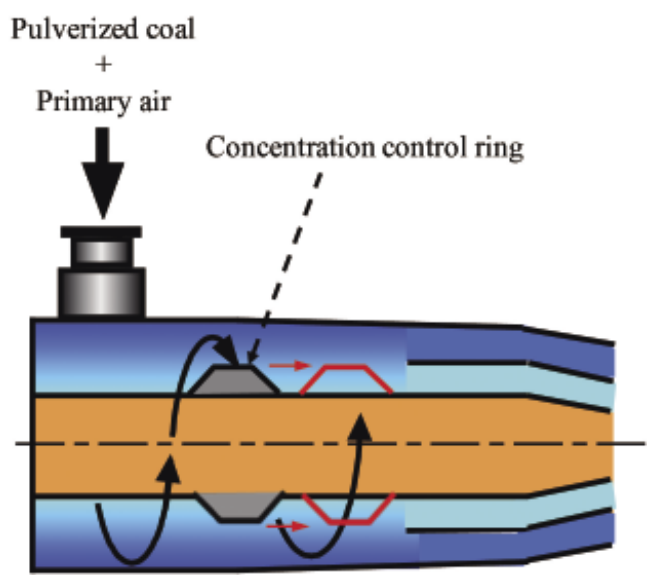

Fig.7 Concept of the wide-range burner.

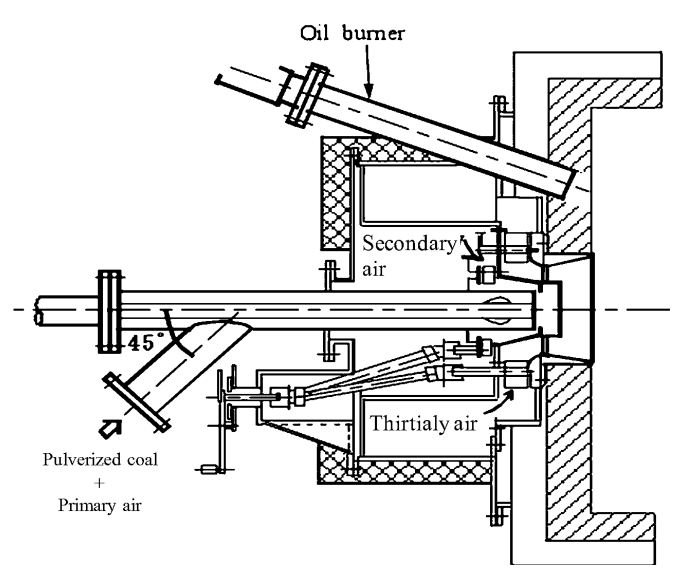

Fig.8 Concept of the CI- $\alpha$ burner. 


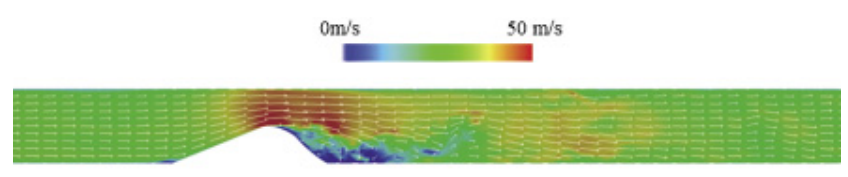

(a) Instantaneous distribution of streamwise velocity

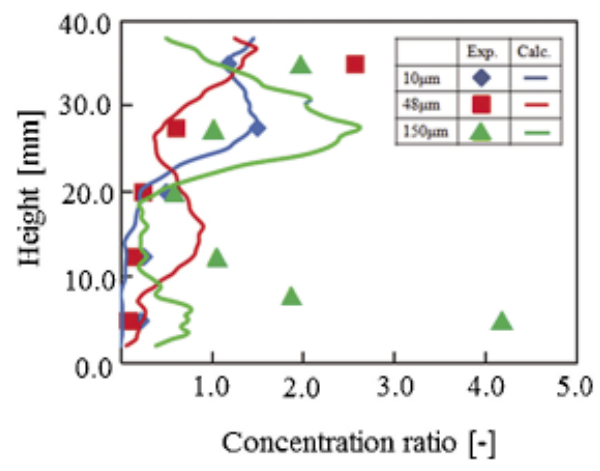

(b) Vertical distributions of concentration ratio

Fig.9 Flow and concentration ratio behavior.

明らかになっている。さらに、旋回流を用いていないため、 3 章で述べた $\mathrm{NO}_{\mathrm{x}}$ 発生量が低く燃焼効率の高い技術との両 立が可能であり、現時点では最も優れた燃焼技術であると 考えられる。

今後は、3 章での記述と同様に、多様な石炭種に対して も低負荷での安定然焼を達成できる必要があり、しかも、 出力変動の大きな自然エネルギーなどの導入に応じて、さ らなる負荷変動能力の向上、最低負荷の低減が必要とされ ると思われる。そのためには、バーナに容易に組み込め、 しかも微粉炭の濃縮機能が高く、かつ濃縮率を速やかに調 整できる微粉炭バーナの開発が必要である。そのための基 礎検討として、濃縮機構周りを対象とした数值シミュレー ション技術の開発も進められている。Fig.9 は濃縮機構周 辺の流れ場の構造および濃縮率である ${ }^{8)}$ 。数值シミュレー ションにより、濃縮機構周辺の流れの構造や、それにより 引き起こされる濃縮現象がよく捉えられていることがわか る。数值シミュレーションを活用することにより、バーナ 開発にむけた実験回数を大幅に低減できるものと考えられ る。

微粉炭など粉体の濃縮には、これまで述べたように、気 流の方向転換などによる慣性力の利用が簡便であるが、さ らなる濃縮性能向上、さらには、慣性力の弱い微粒子の濃 縮を行うためには、静電気力や熱泳動力などの他の作用を 用いた粉体挙動制御方法の利用も有効であると思われる。

また、微粉炭粒子径の微細化は微粉炭の着火性の向上に も有効であり、高度濃縮法の開発とともに、微粉炭粒子径 を一層微細にできる粉砕技術の確立なども今後重要になる
ものと思われる。

\section{5. おわりに}

賦存量が豊富で、今後も主要な化石燃料と考えられてい る石炭の利用法として最も一般的な微粉炭火力において、 その供給力強化のための燃料多様化技術、ならびに電力需 要の変動に対して適切に対応できる負荷追従性向上技術に ついて、最新の研究成果を紹介するとともに、今後期待さ れる技術を概説した。

燃料多様化においては、様々な石炭種に対して低い所要 動力で効果的な微粉砕が可能な技術を開発するとともに、 バーナ噴出後の微粉炭と燃焼用空気との混合過程を最適化 し、高い燃焼効率を維持したまま $\mathrm{NO}_{\mathrm{x}}$ 発生を抑制できる燃 焼技術の開発が重要となる。そのためには、バーナ噴出空 気の噴出角度、流量比、旋回強度が粉体挙動に及ぼす影響 を詳細に解明し、最適な粉体挙動制御技術を確立すること が必要になる。

一方、負荷追従性の改善においては、微粉炭粒子の微細 化による燃焼性向上と、バーナからの噴出直前に、微粉炭 粒子濃度の大幅濃縮を図れるバーナの開発が重要となる。 そのためには、前述した高性能な微粉砕機の開発に加え、 静電気など粉体挙動に大きな影響を持つ粉体の移動作用を 効果的に活用した濃縮法を確立することが必要である。

これらの技術が実現し、ほとんどの石炭種が微粉炭火力 で活用可能になることに加え、炭化していないバイオマス の利用も可能になるなどの燃料多様化が促進されるととも に、電力の必要需要に応じた高速な負荷変化が可能な、一 層スマートな微粉炭火力発電技術が確立されることを祈っ ている。

\section{参考文献}

1) 牧野尚夫、木本政義 : 化学工学論文集、 20 (1994) 747-757.

2) 牧野尚夫、木本政義、氣駕尚志、遠藤善彦 : 火力原子力発電、 48 (1997) 702-710.

3) M. Kimoto, M. Ikeda, H. Makino, T. Kiga and Y. Endo: JSME International Journal, Series B, 41 (1998) 1071-1078.

4) M. Ikeda, H. Makino and Y. Kozai: JSME International Journal, Series B, 45 (2002) 506-511.

5) S.Y. Ahn, T. Syoji, H. Watanabe, N. Hashimoto and K. Tanno: 35th International symposium on combustion (2014).

6) 小谷田一男、沖裕壮、宮前茂広、氣駕尚志：火力原子力発電、 45 (1994) 280-288.

7) 牧野尚夫、木本政義、氣駕尚志、遠藤善彦 : 火力原子力発電、 50 (1999) 790-798.

8) 山本晃、中嶋朗、丹野賢二、辻博文、白井裕三 : 化学工学会 第 79 年会 (2014). 